
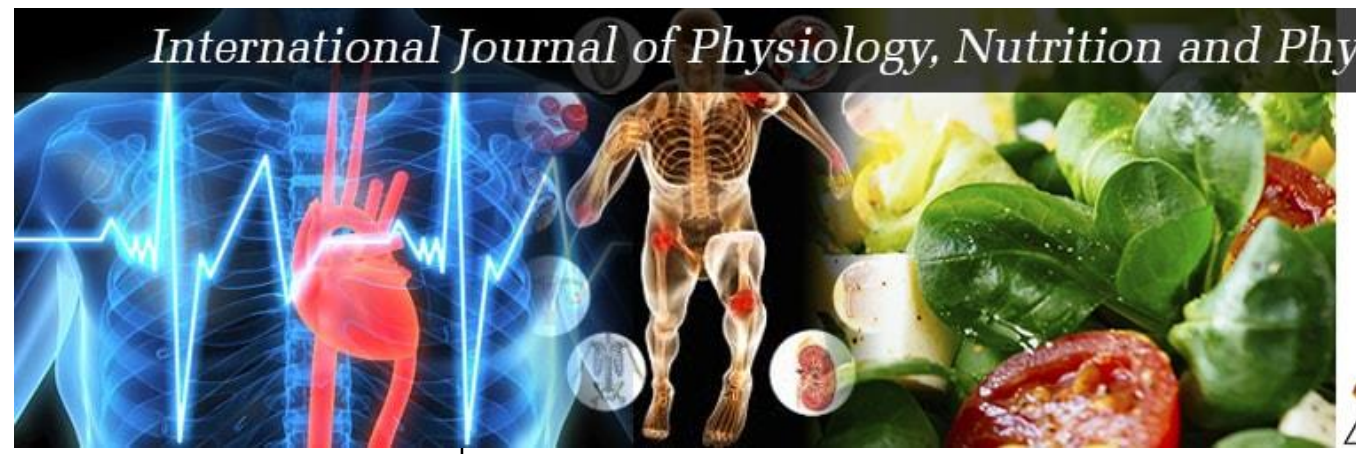

\title{
ysical Education
}

ISSN: $2456-0057$

IJPNPE 2021; 6(1): 152-154

(C) 2021 IJPNPE

www.journalofsports.com

Received: 14-11-2020

Accepted: 23-12-2020

\section{Gagandeep}

Research Scholar, Chaudhary

Devi Lal University, Sirsa,

Haryana, India

\section{Monika Verma}

Professor, Department of

Physical Education, Chaudhary

Devi Lal University, Sirsa,

Haryana, India

\section{Comparative study of indigenous and non-indigenous sports towards self-concept of sports person}

\section{Gagandeep and Monika Verma}

DOI: https://doi.org/10.22271/journalofsport.2021.v6.i1c.2197

\section{Abstract}

This is a survey type of study. The systematic sampling design was used. There are 100 males and 100 female sports persons were randomly selected as subject for this study. The study was conducted only on 100 males and 100 female sports persons. Out of which 50 belongs to rural and 50 belongs to urban respectively. The study was conducted on Indigenous (Kho-Kho and Kabaddi) and Non Indigenous (Football, Basketball) Sports Persons on Sirsa District. To age group of the subjects is 14-18 years. Selfconcept was used Questionnaire R.K. Saraswat (1989). Self-concept variables: Physical Self Concept, Social Self Concept, Temperamental Self Concept, Educational Self Concept, Moral Self Concept, Intellectual Self Concept. The all variables of self-concept which are quite proximate to each other almost Physical, Social, Temperamental, Educational, Moral, Intellectual sports person. There is no significance difference between indigenous and non-indigenous sports towards self-concept of sports persons. The all variables of Indigenous and Non Indigenous sports person self-concept which are quite proximate to each other almost Physical, Social, Temperamental, Educational, Moral, Intellectual sports persons.

Keywords: Indigenous, non-indigenous, sports person, self-concept

\section{Introduction}

Self-concept is an antecedent of good performance which appears to be very important in every area of human activity. One who thinks that he can achieve something, he definitely cantina sports good performance of a person influences his perception about the self. The selfconcept is involved in the formation of hierarchy of concepts of self and the perception about the self. The self-concept is involved in the formation of hierarchy of concepts of self and the perception of it. Self has a standard in whose light other things are judged or felt. It is the cluster of the most personal meaning a person attributes to the self (Kehas, 1962). Research has indicated that the self-concept is an antecedent and consequent variable. While it is predictor of behavior in a certain way it also is consequent on a person's experience and achievements.

\section{Indigenous and non-indigenous}

Over the last 20 years, curriculum development in Health and Physical Education \& Sport Education as it is variously called has repeatedly attempted to address issues of equity and social inclusion. Why then does systemic educational disadvantage persist, and why do the poorest members of society acquire less privileged and privileging forms of Health and Physical Education knowledge, skills and bodily dispositions? What constitutes relevant and responsive Health and Physical Education curriculum for which groups of students remains a site of considerable contestation? At a time when significant changes are being suggested to Health and Physical Education curricula with the development of the India (National) Curriculum, this paper is an attempt to refocus the analysis of education for Indigenous students in Australia upon the power and control relations operating within schools, rather than external social relations, using principles of pedagogic discourse from the sociological theories of Basil. 
The paper contributes to the growing corpus of studies on the social relations within schooling which constitute Health and Physical Education curriculum, and the possibilities for interrupting systemic social inequity through the redesign of school curriculum and pedagogy. Government policy initiatives have reinforced a dominant and persistently negative discourse about 'educational disadvantage' when representing Aboriginal and Torres Strait Islander (Indigenous) students and educational outcomes. This paper challenges these negative discourses and focuses attention on the social relations within schooling which constitute the 'what' and 'how' of Health and Physical Education curriculum, contributing to the large corpus of Bernstein Ian studies of Health and Physical Education curriculum which 'look beneath the surface appearances of progress and innovation, to how inequities endure, despite rhetorical claims to the contrary that they have been eroded or have disappeared'. It also reveals the important contribution that Indigenous communities and educators have made and continue to make to curriculum decision-making in Health and Physical Education for Indigenous India students.

\section{Procedure}

This is a survey type of study. The systematic sampling design was used. There are 100 males and 100 female sports persons were randomly selected as subject for this study. The study was conducted only on 100 males and 100 female sports persons. Out of which 50 belongs to rural and 50 belongs to urban respectively. The study was conducted on Indigenous (Kho-Kho and Kabaddi) and Non Indigenous (Football, Basketball) Sports Persons on Sirsa District. To age group of the subjects is 14-18 years. Self-concept was used Questionnaire R.K. Saraswat (1989).

\section{Self-concept variables}

Physical Self Concept, Social Self Concept, Temperamental Self Concept, Educational Self Concept, Moral Self Concept, Intellectual Self Concept.

\section{Results}

Table 1: Mean and SD values of performance between indigenous and non-indigenous sports on the variable physical self-concept of sports persons

\begin{tabular}{|c|c|c|c|c|c|c|}
\hline \multirow{2}{*}{ Group } & \multicolumn{2}{|c|}{ Indigenous (n= 50) } & \multicolumn{2}{|c|}{ Non-indigenous (n= 50) } & \multirow{2}{*}{ t-value } & df \\
\cline { 2 - 6 } & Mean & SD & Mean & SD & 1.00 & 1.58 \\
\hline Physical & 17.55 & 3.69 & 16.69 & 198 & 0.12 \\
\hline
\end{tabular}

**Significant at 0.01 level

Table 1. Presents the variable Physical Self Concept. The value on the Indigenous and non- indigenous group. The average Indigenous score was $\mathrm{M}=17.55, \mathrm{SD}=3.69$ and nonindigenous score $\mathrm{M}=16.69, \mathrm{SD}=4.00$ respectively. The value of the Degree of Freedom is 198. The difference between Indigenous and non- indigenous group on Physical Self Concept of these two groups, analyses independently using a t-test, was $\mathrm{t}$ (1.58). According to these results, there is statistically significant difference between the Indigenous and non- indigenous group scores of on Physical Self Concept was statistically of these two groups at the 0.01 level $(\mathrm{p}=$ $0.12 ; p<.01)$. The $\mathrm{p}$-value is less than the 0.01 level of significant. So, the result of the ' $t$ ' test analysis indicated that the researcher must aspect hypothesis.

Table 2: Mean and SD values of performance between indigenous and non-indigenous sports on the variable social self-concept of sports persons

\begin{tabular}{|c|c|c|c|c|c|c|c|}
\hline \multirow{2}{*}{ Group } & \multicolumn{2}{|c|}{ Indigenous (n= 50) } & \multicolumn{2}{|c|}{ Non-indigenous (n= 50) } & \multirow{2}{*}{ t-value } & \multirow{2}{*}{ df } & \multirow{2}{*}{ p-value } \\
\cline { 2 - 8 } & Mean & SD & Mean & SD & & 198 & $0.00^{* *}$ \\
\hline Social & 19.11 & 3.27 & 17.57 & 3.56 & 3.19 & 198 \\
\hline
\end{tabular}

**Significant at 0.01 level

Table 2. Presents the variable Social Self Concept. The value on the Indigenous and non- indigenous group. The average Indigenous score was $\mathrm{M}=19.11, \mathrm{SD}=3.27$ and nonindigenous score $\mathrm{M}=17.57, \mathrm{SD}=3.56$ respectively. The value of the Degree of Freedom is 198. The difference between Indigenous and non- indigenous group on Social Self Concept of these two groups, analyses independently using a t-test, was $\mathrm{t}$ (3.19). According to these results, there is statistically significant difference between the Indigenous and non- indigenous group scores of on Social Self Concept was statistically of these two groups at the 0.01 level $(\mathrm{p}=0.00 ; p$ $<.01$ ). The p-value is less than the 0.01 level of significant. So, the result of the ' $t$ ' test analysis indicated that the researcher must aspect hypothesis.

Table 3: Mean and SD values of performance between indigenous and non-indigenous sports on the variable temperamental self-concept of sports persons

\begin{tabular}{|c|c|c|c|c|c|c|c|}
\hline \multirow{2}{*}{ Group } & \multicolumn{2}{|c|}{ Indigenous $(\mathbf{n}=\mathbf{5 0})$} & \multicolumn{2}{|c|}{ Non-indigenous $(\mathbf{n}=\mathbf{5 0})$} & \multirow{2}{*}{ t-value } & \multirow{2}{*}{ df } & p-value \\
\cline { 2 - 8 } & Mean & SD & Mean & SD & & 198 & $0.00 * *$ \\
\hline Temperamental & 18.25 & 3.58 & 16.84 & 4.03 & 2.61 & 198 \\
\hline
\end{tabular}

**Significant at 0.01 level

Table 3. Presents the variable Temperamental Self Concept. The value on the Indigenous and non- indigenous group. The average Indigenous score was $\mathrm{M}=18.25 \mathrm{SD}=3.58$ and nonindigenous score $\mathrm{M}=16.84, \mathrm{SD}=4.03$ respectively. The value of the Degree of Freedom is 198. The difference between Indigenous and non- indigenous group on Temperamental Self Concept of these two groups, analyses independently using a t-test, was $t$ (2.61). According to these results, there is statistically significant difference between the Indigenous and non-indigenous group scores of on Temperamental Self Concept was statistically of these two groups at the 0.01 level $(\mathrm{p}=0.00 ; p<.01)$. The $\mathrm{p}$-value is less than the 0.01 level of significant. So, the result of the ' $t$ ' test analysis indicated that the researcher must aspect hypothesis. 
Table 4: Mean and SD values of performance between indigenous and non-indigenous sports on the variable educational self-concept of sports persons

\begin{tabular}{|c|c|c|c|c|c|c|c|}
\hline \multirow{2}{*}{ Group } & \multicolumn{2}{|c|}{ Indigenous $(\mathbf{n}=\mathbf{5 0}$ ) } & \multicolumn{2}{|c|}{ Non-indigenous $(\mathbf{n}=\mathbf{5 0})$} & \multirow{2}{*}{ t-value } & \multirow{2}{*}{ df } & \multirow{2}{*}{ p-value } \\
\hline & Mean & SD & Mean & SD & & & \\
\hline Educational & 16.94 & 3.74 & 18.01 & 4.28 & -1.88 & 198 & 0.06 \\
\hline
\end{tabular}

**Significant at 0.01 level

Table 4. Presents the variable Educational Self Concept. The value on the Indigenous and non- indigenous group. The average Indigenous score was $\mathrm{M}=16.94, \mathrm{SD}=3.74$ and nonindigenous score $\mathrm{M}=18.01, \mathrm{SD}=4.28$ respectively. The value of the Degree of Freedom is 198. The difference between Indigenous and non- indigenous group on Educational Self Concept of these two groups, analyses independently using a t-test, was $\mathrm{t}(-1.88)$. According to these results, there is statistically significant difference between the Indigenous and non- indigenous group scores of on Educational Self Concept was statistically of these two groups at the 0.01 level $(\mathrm{p}=0.06 ; p<.01)$. The $\mathrm{p}$-value is less than the 0.01 level of significant. So, the result of the ' $t$ ' test analysis indicated that the researcher must aspect hypothesis.

Table 5: Mean and SD values of performance between indigenous and non-indigenous sports on the variable moral self-concept of sports persons

\begin{tabular}{|c|c|c|c|c|c|c|c|}
\hline \multirow{2}{*}{ Group } & \multicolumn{2}{|c|}{ Indigenous $(\mathrm{n}=\mathbf{5 0})$} & \multicolumn{2}{|c|}{ Non-indigenous $(n=50)$} & \multirow[b]{2}{*}{ t-value } & \multirow[b]{2}{*}{ df } & \multirow[b]{2}{*}{ p-value } \\
\hline & Mean & SD & Mean & SD & & & \\
\hline Moral & 16.89 & 3.55 & 16.29 & 3.20 & 1.25 & 198 & 0.21 \\
\hline
\end{tabular}

**Significant at 0.01 level

Table 5 presents the variable Moral Self Concept. The value on the Indigenous and non- indigenous group. The average Indigenous score was $\mathrm{M}=16.89, \mathrm{SD}=3.55$ and nonindigenous score $\mathrm{M}=16.29, \mathrm{SD}=3.20$ respectively. The value of the Degree of Freedom is 198. The difference between Indigenous and non- indigenous group on Moral Self Concept of these two groups, analyses independently using a t-test, was $\mathrm{t}$ (1.25). According to these results, there is statistically significant difference between the Indigenous and non- indigenous group scores of on Moral Self Concept was statistically of these two groups at the 0.01 level $(p=0.06 ; p$ $<.01)$. The $\mathrm{p}$-value is less than the 0.01 level of significant. So, the result of the ' $t$ ' test analysis indicated that the researcher must aspect hypothesis.

Table 6: Mean and SD values of performance between indigenous and non-indigenous sports on the variable intellectual self-concept of sports persons

\begin{tabular}{|c|c|c|c|c|c|c|c|}
\hline \multirow{2}{*}{ Group } & \multicolumn{2}{|c|}{ Indigenous $(\mathbf{n}=\mathbf{5 0})$} & \multicolumn{2}{|c|}{ Non-indigenous $(\mathbf{n}=\mathbf{5 0})$} & \multirow{2}{*}{ t-value } & \multirow{2}{*}{ df } & \multirow{2}{*}{ p-value } \\
\cline { 2 - 5 } & Mean & SD & Mean & SD & & 198 & 0.40 \\
\hline Intellectual & 20.19 & 4.12 & 20.71 & 4.51 & -0.85 & 198 \\
\hline
\end{tabular}

**Significant at 0.01 level

Table 6. Presents the variable Intellectual Self Concept. The value on the Indigenous and non-indigenous group. The average Indigenous score was $\mathrm{M}=20.19 \mathrm{SD}=4.12$ and nonindigenous score $\mathrm{M}=20.71, \mathrm{SD}=4.51$ respectively. The value of the Degree of Freedom is 198. The difference between Indigenous and non-indigenous group on Intellectual Self Concept of these two groups, analyses independently using a t-test, was $t(-0.85)$. According to these results, there is statistically significant difference between the Indigenous and non-indigenous group scores of on Intellectual Self Concept was statistically of these two groups at the 0.01 level ( $\mathrm{p}=0.40 ; p<.01)$. The $\mathrm{p}$-value is less than the 0.01 level of significant. So, the result of the ' $t$ ' test analysis indicated that the researcher must aspect hypothesis.

\section{Discussion}

The all variables of self-concept which are quite proximate to each other almost Physical, Social, Temperamental, Educational, Moral, Intellectual sports person.

There is no significance difference between indigenous and non-indigenous sports towards self-concept of sports persons.

\section{Conclusions}

The all variables of Indigenous and Non Indigenous sports person self-concept which are quite proximate to each other almost Physical, Social, Temperamental, Educational, Moral, Intellectual sports persons.

\section{References}

1. Bogart Kathleen R. Rehabilitation Psychology, the role of disability self-concept in adaptation to congenital or acquired disability 2014;59(1):107-115.

2. Darren Treasure C et al. Relationship between Female Adolescents Achievement Goal Orientations, Perceptions of the Motivation Climate, Belief about success and sources of satisfaction in Basketball. International Journal of Sports psychology 1998;29(3):211-230.

3. Gill JK. A study of self-concept with special reference to performance and gender of athletes in the age group of 18 to 22 years. Unpublished Master's Dissertation, Department of Physical Education, Punjab University, Chandigarh 1994.

4. Gill JK. Sports Performance Motivation, Self-Concept and Extroversion of female athletes in relation to their performance 1998.

5. Kamal AF. Self-esteem attributional components of athletes versus non-athletes. International Journal of Sport Psychology 1995;26(2):189-195. 